\title{
SIMULATION OF KINETIC PROCESSES, OPTICAL AND NEUTRON PROPERTIES OF THE NUCLEAR-EXCITED DUSTY PLASMA OF NOBLE GASES
}

\author{
A.P. BUDNIK, L.V. DEPUTATOVA, V.E. FORTOV, V.P. LUNEV, \\ V.I. VLADIMIROV
}

$\begin{array}{ll}\text { PACS 28.20.-v; 36.40.Wa; } & \text { Joint Institute of High Temperatures, Russian Academy of Sciences } \\ \text { 52.25.Dg } & (13 / 19 \text {, Izhorskaya Str., Moscow 127412, Russia; e-mail: dlv@ihead. ras. ru })\end{array}$

(c) 2011

A model of kinetic processes in the argon-xenon gas plasma with the admixture of uranium nanoclusters is developed. This dusty plasma seems to be perspective as an active laser medium in the technologies of direct conversion of the nuclear energy into coherent light. The process of formation of quasistationary states in plasma and the influence of uranium nanoclusters are considered in the developed mathematical model of the kinetic processes in the argon-xenon gas excited by nuclear fission fragments. The suggested system of equations allows one to describe the kinetic processes in the plasma with presence of the uranium dust in a self-consistent way. The model include the evolutionary equations for the distribution function of electron velocities and for concentrations of a different components of plasma, including charged uranium nanoclusters. The model takes 44 components of plasma and 507 plasma-chemical processes into account. The method of solution of such equations is suggested, and the program complex realizing this method is developed. The influence of the dust concentration on the optical and neutronic properties of the plasma media is studied in calculations. The calculation of the neutron multiplication factor for the laser active infinite medium containing uranium dust particles is performed with the use of MCNP5 code. The neutron cross-sections needed for calculations were taken from the ENDF/b-VI library. The attenuation of electromagnetic waves by uranium dust particles was calculated in the frame of the Mie theory for various spherical particle sizes and different wavelengths. Real and imaginary parts of the refraction coefficient for uranium needed for this calculation were taken from the experimental and theoretical works.

\section{Introduction}

In the present time, the nuclear excited dusty plasma has been intensively investigated $[1,2]$, because this active media seems promising for the direct nuclear energy conversion to optical radiation. This technology has not been actually investigated due to the strict nuclear safety requirements for radioactive aerosols and reasonable technical difficulties.

Recently, the first theoretical investigation of the Uranium Dusty Argon Xenon Medium (UDAXM) has con- firmed the laser radiation gain for a wavelength of 1.73 $\mu \mathrm{m}[3]$.

This paper considers the laser active medium consisting of a mixture of noble gas with fine particles of uranium. As an example, we show the results of our investigation of UDAXM as an active laser medium for wavelengths of 2.03 and $2.65 \mu \mathrm{m}$. We simulated the kinetic processes in UDAXM and studied the optical properties of such nuclear excited dusty plasma, as well as the neutron multiplication factor.

The main goal of this work is to substantiate the nuclear excited dusty plasma of noble gas with uranium fine particles as an efficient active laser medium for nuclear pumped lasers.

\section{Optical and Neutron Properties of Laser Media}

Important parameters of the laser active medium containing uranium dust particles are the neutron multiplication factor and the extinction cross-section of the medium. The first parameter describes the neutronic property of the dusty gas medium. The ability of such media for the neutron multiplication is expressed by the neutron multiplication factor $K_{\text {eff }}$. The multiplication of neutrons in those media allows us to use a large-volume laser active medium. The calculation of the neutron multiplication factor for the laser active medium containing uranium dust particles is performed, by using MCNP-5 code [4]. The neutron cross-sections needed for calculations were taken from the ENDF/b-VI library [5]. The calculation was performed for infinite UDAXM containing spherical uranium particles with a radius of $10 \mathrm{~nm}$. The isotope concentrations were $95 \%$ of $\mathrm{U}^{235}$ and $5 \%$ of $\mathrm{U}^{238}$. The calculated neutron multiplication factor for the infinite laser active media versus the dust particles concentration is presented in Fig. 1. Based on these data, we can conclude that the laser active medium with 


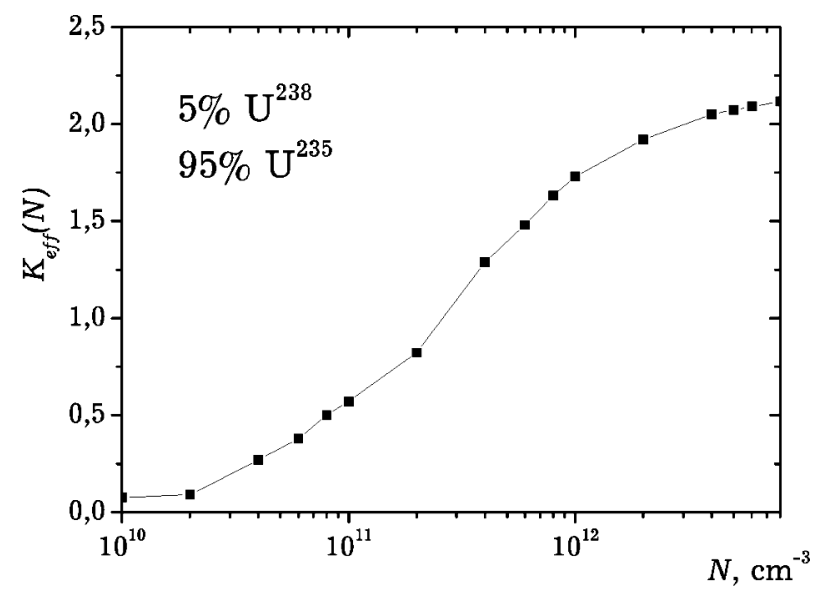

Fig. 1. Neutron multiplication factor for the infinite UDAXM versus the concentration of dust particles

the concentration of uranium particles more than $3 \cdot 10^{11}$ $\mathrm{cm}^{-3}$ can multiply neutrons.

The second parameter describes the optical property of the active medium. The attenuation of the electromagnetic wave by uranium dust particles is calculated in the frame of the Mie theory for various spherical particle sizes and different wavelengths. Real and imaginary parts of the refraction coefficient for uranium needed for this calculation are taken from the experimental work [6]. The fission fragment energy deposition into a laser active medium directly depends on the fissile element concentration. So it is convenient to use a volume extinction cross-section equal to the ratio of the extinction cross-section to the particle volume $V$. The calculated volume extinction cross-sections for wavelengths of 0.5 , 1.0 , and $2.03 \mu \mathrm{m}$ versus the radius of uranium dust particles are presented in Fig. 2.

\section{Kinetic Model}

The formerly developed model [3] of the kinetic processes in argon-xenon gas plasma has to be completed by the processes of interaction of electrons and ions with charged dust particles. This additional processes are described schematically by following equations:

$e+D \rightarrow D(-)$

$e+D(n-) \rightarrow D((n+1)-)$

$I(+)+D(n-) \rightarrow D((n-1)-) ;$

$I(+)+D \rightarrow D(+)$,

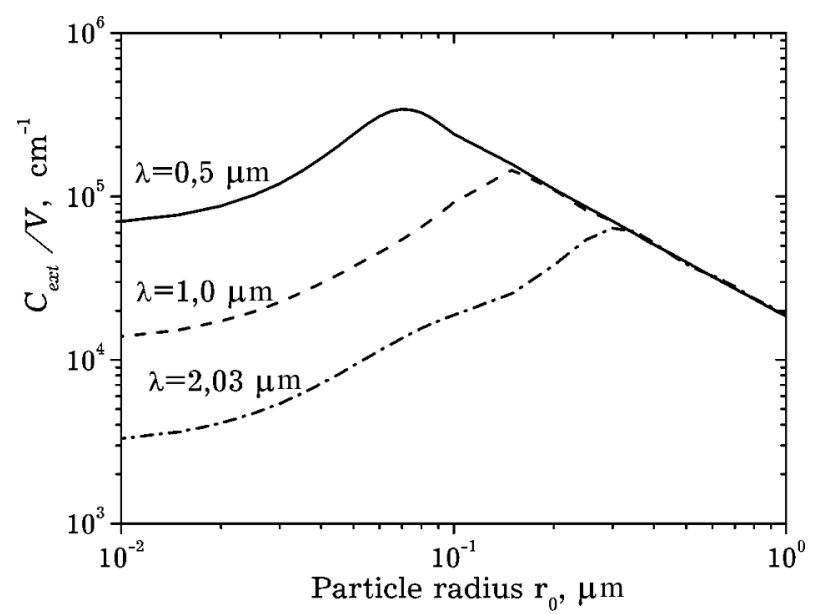

Fig. 2. Volume extinction cross-sections for wavelengths of 0.5 , 1.0 , and $2.03 \mu \mathrm{m}$ as a function of the radius of dust particles

where $e$ is an electron, $D, D(n-), D(+)$ are neutral, negative, and positive charged dust particles, respectively, $n$ is the dust charge number (in the electron charge units), $I(+)$ is any positive charged atomic or molecular ion. The kinetic model of the processes in UDAXM includes 44 components of plasma and takes 505 reactions into account. It is important to note that, due to a relatively low value of dust particles charges, we should take the charge discreteness into account in the mathematical simulation of the charge transfer to dust particles.

Neglecting a space non-uniformity and, as a corollary, the influence of an electrical field, we consider the process of dust plasma creation by fission fragments. Then, assuming the slightly ionized plasma and the charge of dust particles to be negative, we describe the plasma evolution by the system of equations

$$
\frac{\partial f_{0}(v, t)}{\partial t}=S_{0}\left(f_{0},\left\{N_{k}\right\}\right)+j_{\mathrm{FF}}(t) N_{a} \frac{d \sigma_{i}(v)}{d v}-
$$

$-\sum_{i} \pi r_{0}^{2} \gamma_{e} v Y(i) \theta(Y(i)) N_{\text {dust }}(i) f_{0}(v, t)$

$$
\begin{aligned}
& \frac{\partial N_{k}(t)}{\partial t}=\sum_{m} R_{k m}+\sum_{i} f_{\mathrm{dust}, k, i}^{\mathrm{ion}} N_{\mathrm{dust}}(i)+ \\
& +j_{\mathrm{FF}}(t) N_{a} \sigma_{k}+\sum_{k^{\prime}} A_{k k^{\prime}} N_{k^{\prime}}-\sum_{k^{\prime}} A_{k^{\prime} k} N_{k^{\prime}}
\end{aligned}
$$

$\frac{\partial N_{\mathrm{dust}}(i)}{\partial t}=\sum_{k} f_{\mathrm{dust}, k, i+1}^{\mathrm{ion}} N_{\mathrm{dust}}(i+1)-G(i)$, 


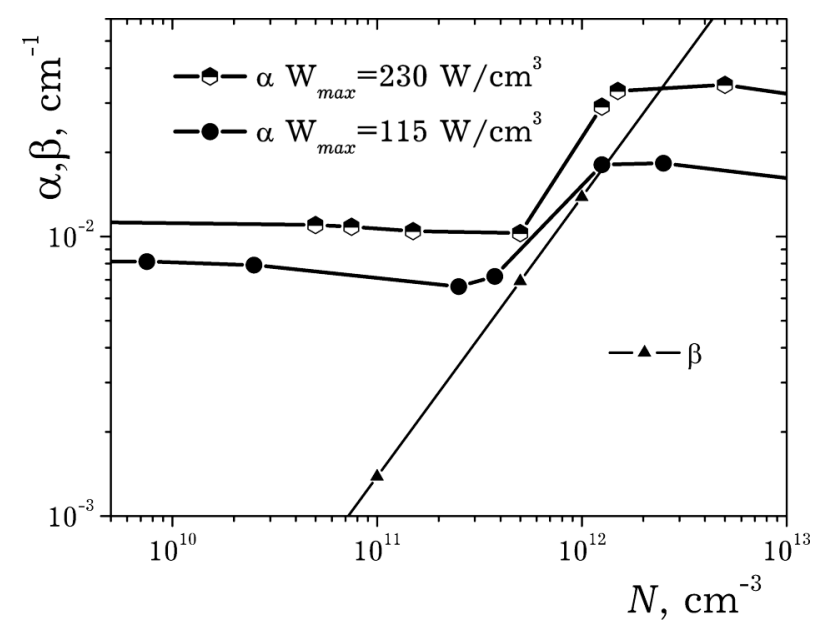

Fig. 3. Light linear gain $\alpha$ of the gas medium and the extinction $\beta$ for uranium particles versus the dust particle concentration

$Y(i)=1-\frac{i e^{2}}{r_{0} \varepsilon}$,

$G(i)=F_{1}(i)-F_{1}(i+1)$

$F_{1}=\gamma_{e} \int_{0}^{\infty} 4 \pi^{2} v^{3} r_{0}^{2} Y(i) \theta(Y(i)) N_{\text {dust }}(i) f_{0}(v, t) d v$

Here, $t$ is the time, $v$ is an electron velocity, $f_{0}(v, t)$ is a symmetric part of the distribution function of electron velocities, $S_{0}\left(f_{0},\left\{N_{k}\right\}\right)$ is a collision integral including both inelastic and elastic collisions of electrons with heavy particles and electron-electron collisions [7], the quantity $\left\{N_{k}(t)\right\}$ indicates a combination of variables determining the density of all considered particles, $N_{e}(t)$ is the electron density, $N_{k}(t)$ is the density of the $k$-kind particles (atoms, molecules, ions, etc., in the ground or excited state), $N_{\text {dust }}(i)$ is the density of dust particles with the charge $z=-i e, r_{0}$ is the dust grain radius, $\varepsilon=m v^{2} / 2$ is the electron kinetic energy, $e$ and $m$ are the elementary charge and the electron mass, $\gamma_{e}$ is the probability that an electron falling on the surface of a dust grain transfers the charge to it, $j_{\mathrm{FF}}(t)$ is the flux density of fission fragments, $\frac{d \sigma_{i}(v)}{d v}$ is the differential cross-section of electron emission with velocity $v$ by an atom in the interaction with a fission fragment, $N_{A}$ is the density of gas atoms, $\sigma_{k}$ is the cross-section of the formation of $k$-kind particles in the interaction of fission fragments with atoms, $A_{k k^{\prime}}$ is the Einstein first factor, $\theta(x)$ is the Heaviside theta-function,

$R_{k m}=k_{k m}^{f} \prod_{k} N_{k}^{\beta_{k}(m)}-k_{k m}^{b} \prod_{k} N_{k}^{\alpha_{k}(m)}$

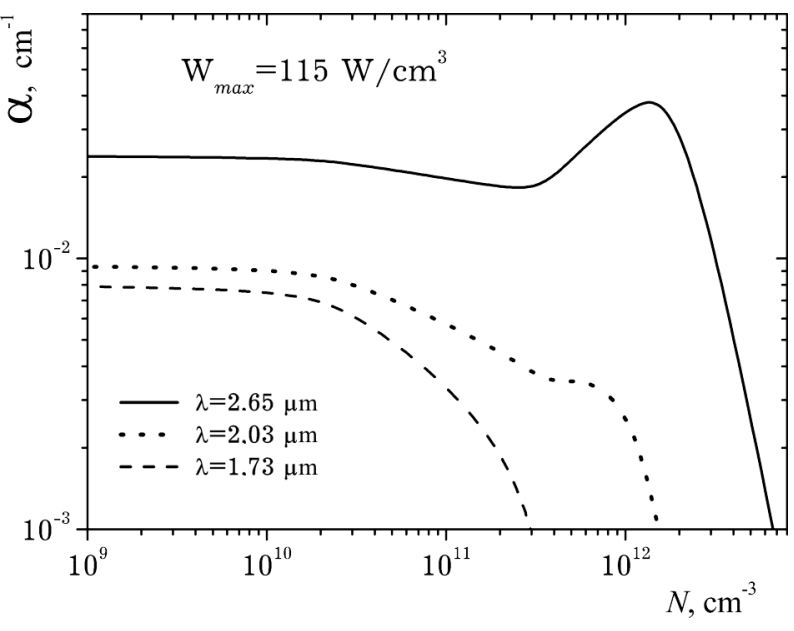

Fig. 4. Light linear gain by the laser active medium versus the concentration of uranium dust particles

is the $m$-type reaction rate, $\beta_{k}(m), \alpha_{k}(m)$ are stoichiometric factors of the $m$-type reaction, and $k_{k m}^{f}$ and $k_{k m}^{b}$ are the rate constants of the direct and reverse reactions, respectively.

The function $f_{\text {dust }, k, i}^{\text {ion }}$ represents the charge transfer rate from the $k$-type ion to a dust particle with the charge $z=-i e$. For this function, we used the approximation suggested in [7].

\section{Results of Mathematical Simulation of Kinetic Processes}

The simulation of kinetic processes in dusty plasma allows us to calculate the concentration of any plasma component. Consequently, we can obtain the light linear gain by the laser medium. The starting values of gas pressure and temperature were equal to 1 at and 300 K. It was adopted that the specific energy deposition power of fission fragments was increasing linearly during $1 \mu \mathrm{s}$ from zero up to $W_{\max }$ and became permanent after that. The calculation was performed for UDAXM containing spherical uranium particles with a radius of $10 \mathrm{~nm}$.

The typical results of calculations of the light linear gain $\alpha$ by the gas phase and the extinction by uranium particles $\beta$ are shown in Fig. 3. The calculations were performed for a wavelength of $1.73 \mu \mathrm{m}$ and the power deposition maxima $W_{\max }=115 \mathrm{~W} / \mathrm{cm}^{3}$ and $W_{\max }=230 \mathrm{~W} / \mathrm{cm}^{3}$ for different concentrations of dust particles.

The light linear gains by the laser active medium considering the extinction of particles for wavelengths 
of $1.73,2.03$, and $2.65 \mu \mathrm{m}$ versus the concentration of dust particles for $W_{\max }=115 \mathrm{~W} / \mathrm{cm}^{3}$ are shown in Fig. 4.

\section{Conclusion}

A new theoretical model of the kinetic, optical and neutron processes in UDAXM is developed. It is shown that UDAXM seems a promising medium in the technologies of the direct conversion of the nuclear energy into coherent light if we will use uranium nanoclusters.

The work was supported by RFBR, grants N 080800456 and 100800997.

1. V.E. Fortov, A.P. Nefedov, V.I. Vladimirov, L.V. Deputatova, A.P. Budnik, A.V. Khudyakov, and V.A. Rykov, Phys. Lett. A 284, 118 (2001).

2. V.E. Fortov, V.A. Rykov, A.P. Budnik, V.S. Filinov, L.V. Deputatova, K.V. Rykov, V.I. Vladimirov V.I. Molotkov, A.V. Zrodnikov, and P.P. Dyachenko, Phys. Lett. A 351, 296 (2006).

3. A.P. Budnik, V.A. Kosarev, and V.P. Lunev, in Proc. of the IV Int. Confer. on Physics of Nuclear Pumped Lasers and Pulse Reactors (IPPE, Obninsk, 2007).

4. X5-Monte Carlo Team, Report LA-UR-03-1987, Los Alamos, April 2003.

5. P.F. Rose, BNL-NCS-17541, Brookhaven National Laboratory, October 1991.

6. A. Faldt and P.O. Nilsson, J. of Phys. F: Met. Phys. 10, 2573 (1980).

7. B.M. Smirnov, Aerosols in Gas and Plasma (IVTAN, Moscow, 1990) (in Russian).

Received 17.03.11
МОДЕЛЮВАННЯ КІНЕТИЧНИХ ПРОЦЕСІВ

ТА ОПТИЧНИХ І НЕЙТРОННИХ ВЛАСТИВОСТЕЙ ЗАПИЛЕНОЇ ПЛАЗМИ БЛАГОРОДНИХ ГАЗІВ ПРИ ЗБУДЖЕННІ ПРОДУКТАМИ ПОДІЛУ ЯДЕР

А.П. Будник, Л.В. Депутатова, В.Е. Фортов, В.П. Лунєв, В.І. Владимиров

$\mathrm{P}$ е $з$ ю м е

Розроблено модель кінетичних процесів у ядерно-збуджуючій плазмі інертних газів, що має нанокластери урану. Таку пилову плазму подано найбільш перспективним активним лазерним середовищем у технології прямого перетворення ядерної енергії у когерентне електромагнітне випромінювання.

Розглянуто процес формування квазістаціонарних станів плазми, запиленої нанокластерами урану. За допомогою розробленої математичної моделі кінетичних процесів в аргонксеноновій плазмі, що збуджується осколками поділу урану, вивчено вплив нанокластерів урану на генераційні характеристики цього середовища.

Кінетична модель складається 3 еволюційних рівнянь для функції розподілу електронів за швидкостями і для концентрацій різних компонентів плазми, враховуючи пилові частинки урану з різними зарядами. У моделі аргон-ксенонової плазми враховується 44 компоненти плазми та 507 плазмохімічних реакцій.

Розроблено метод числового обчислення і створено комплекс програм для моделювання кінетичних процесів у ядернозбуджуючій плазмі інертних газів з урахуванням впливу на ці процеси нанокластерів. Проведено самоузгоджене математичне моделювання кінетичних процесів у газі, що збуджується осколками поділу урану з урахуванням впливу на ці процеси пилових частинок.

Задачу взаємозв'язку нейтронного випромінювання з газовим середовищем, що має частинки урану, розв'язували методом Монте-Карло за допомогою програми MCNP-5. Перерізи нейтронних реакцій, необхідні для проведення розрахунків, взято із бібліотеки нейтронних даних ENDF/b-VI. Послаблення електромагнітного випромінювання урановими частинками обчислено за теорією Мі для різної довжини хвилі і частинок різних розмірів. Комплексні коефіцієнти заломлення металічного урану виявляли згідно з експериментальними даними і теоретичними оцінками. 